\title{
In situ Enriched Compost Preparation from Rice and Wheat Straw using Tender Sunnhemp to Minimise Field Burning
}

\author{
A. K. Ghorai* \\ ICAR-Central Research Institute for Jute and Allied Fibres, \\ Barrackpore, Kolkata-120, WB, India \\ *Corresponding author
}

\section{A B S T R A C T}

\section{Keywords \\ Wheat straw, Rice straw, Sunnhemp, Enriched compost, Easy compost, Nutrient composition}

\section{Article Info}

Accepted: 07 August 2020 Available Online: 10 September 2020
India is endowed with plenty of renewable wheat and rice straw, around 300 million tonnes annually. Due to its poor $\mathrm{C}$ : $\mathrm{N}$ ratio it does not decompose easily which can be accelerated using tender sunnhemp, rich in nitrogen. Thus enriched compost from rice and wheat straw was made using tender sunnhemp plants (45 DAS). Composts were also made from rice and wheat straw using other additives like mustard cake, field soil, FYM and N, P, K: : 10: 26: 26 . The composting process took 4-6 months. The manure was doughed and moulded to blocks to retain its nutrients for longer time. The sunnhemp and straw compost is dark in colour, odor less, easy to handle and contains 1.95 per cent nitrogen, 0.848 per cent phosphorus. The bulk density of the said material is $0.4-0.5 \mathrm{~g} / \mathrm{cc}$. Available, phosphorus and potassium were 0.001 and 0.208 per cent respectively. It is estimated that around 200-300 million tonnes of enriched compost can be made annually in India. Composting from rice/wheat straw burning of wheat and rice straw minimises at large and maintain clean environment along with supply of plant nutrients to the hungry soil.

\section{Introduction}

The role of organic matter in agriculture is well established. It is highly relevant to the cultivated soils of tropical and sub-tropical countries, poor in organic matter and major plant nutrients, due to high temperature, rainfall and accelerated microbial activity. Further there is a wide gap between annual nutrient removal in large quantities by the crops and the supply of chemical fertilizers not to mention their high cost and adverse environmental impact. Thus the net balance has to be replenished by recycling the ecofriendly organic manures, the only way, to foster soil health, eco-technological stability, and sustainable agriculture and as a worthy basic input to organic farming.

But inadequate application of organic matter in soil due to its poor availability has remained a reality. Given the inescapable practice of burning of around $29 \%$ of cattledung in rural India, there is urgent need to look for alternative sources of organic manures. The cattle-dung production is also 
gradually reducing due to fast replacement of animal power in agriculture through mechanization. These straws are also poor cattle food owing to its high silica content. Of late, large scale rice and wheat straw burning (Fig. 1) has created a great social and environmental concern which needs to be addressed immediately.

Burning of rice straw helps in removal of huge volumes of biomass, weed control and a variety of pests and diseases (Ponnamperuma 1984) in crop field. But burning of rice straw invites nutrient loss, reduction of soil organic matter (SOM), and reduction in beneficial soil micro organisms (Mandal et al., 2004).

Rice straw burning causes greenhouse gas emissions (GHGE), that includes $0.7-4.1 \mathrm{~g}$ of $\mathrm{CH}_{4}$ and $0.019-0.057 \mathrm{~g}$ of $\mathrm{N}_{2} \mathrm{O}$ per kg of dry rice straw, including other pollutants like $\mathrm{SO}_{2}$, $\mathrm{NOx}, \mathrm{HCl}$ and, to some extent, dioxins and furans (Oanh et al., 2011, Jenkins et al., 2003). It is also a source of aerosol particles like coarse dust particles $\left(\mathrm{PM}_{10}\right)$ and fine particles $\left(\mathrm{PM}_{2.5}\right)$ (Chang et al., 2013), which affects local air quality and earth's radiation budget (Engling et al., 2009).

For these reasons open-field straw burning has been strictly banned or regulated in crop fields around the world.

The total carbon dioxide equivalent $\left(\mathrm{CO}_{2}\right.$-eq) per ha converted from $\mathrm{CH}_{4}$ and $\mathrm{N}_{2} \mathrm{O}$ with straw incorporation in rice season emitted about $3,500 \mathrm{~kg} \mathrm{CO}_{2}$-eq per ha. This amount of GHGE was almost 1.5 times higher than the amount emitted from the practice of rice straw removal (IIRI).Fortunately, India is endowed with plenty (around 300 million tonnes annually) of renewable wheat and rice straw (41\% C, 0.5-0.8\% N, 0.05- 0.8\% P and 0.3$2.0 \%$, IRRI Rice Knowledge Bank) which can be converted to enriched manures by composting it with sunhemp (Crotalaria juncea, $0.72 \% \quad \mathrm{~N}, 0.12 \% \quad \mathrm{P}_{2} \mathrm{O}_{5}$ and $0.51 \%$ $\mathrm{K}_{2} \mathrm{O}$ ), most of which is currently burnt in the field itself. About 13 tonnes of carbon dioxide from one hectare rice land mixes in air annually and pollutes the environment.

Compost from cereal residues of low $\mathrm{C}$ : $\mathrm{N}$ ratio using legume/FYM in 2:1 ratio has been described in IRRI Rice Knowledge bank (www.knowledgebank.irri.org). Composting from rice straw using different microbes or other additives have also been reported by many scientists (Manna and Sahu 2013, Rashid et al., 2001)) across the world but none has been used successfully and commercially till date in any country.

Large-scale production of in situ enriched compost using tender sunnhemp with cereal residues will solve the problem of lack of nutrient rich organic matter in organic farming, which are otherwise burnt.

Due to poor C: $\mathrm{N}$ ratio in rice /wheat straw, it does not decompose easily which can be accelerated using sun hemp, rich in nitrogen. Sun hemp being a $\mathrm{C} 4$ plant will absorb huge quantity of carbon dioxide from the atmosphere in short period (around 5-6 tonnes/ha) and will bind in the form of green herbage. It is estimated that around 200-300 million tonnes of enriched compost can be made annually in India, which will minimise the problem of shortage of organic matter in the country.

The same practice can be adopted in other tropical countries of the world too, where there is surplus wheat and rice straw and sunhemp can be grown commercially. Preparation of this enriched compost seems to be one solution in right direction enhancing dynamism and sustenance to sun hemp cultivation. Sunnhemp has to be grown after wheat or summer rice for 45 days. 


\section{Materials and Methods}

\section{Enriched compost from straw and sunnhemp}

This enriched straw compost was prepared at ICAR-CRIJAF, Barrackpore in 2104, 2015, 2016 and 2017. The method was verified and tested in fa farmer's field at village, Kalapunja, Paschim Midnapur, WB in 2016. The manure was prepared in concrete rectangular chamber of dimension $5 \mathrm{~m} \times 1 \mathrm{~m}$ $\mathrm{x} 1.5 \mathrm{~m}$. The floor was properly cleaned and sealed for leakage. The sunnhemp crop was grown up to 45 days, and harvested by motorized brush cutter from ground level (Fig. 2) and were brought to the compost chamber. These freshly cut plants were chopped into pieces (6-8") by sickle and spread on the chamber floor up to 1 foot. Chopped wheat straw, obtained after mechanical threshing of wheat was spread over the sunnhemp layer, of 1 foot depth (Fig. $3)$. The process was repeated for three times. No cover was made over it and it was under a mango groove. Similarly freshly threshed rice straw (unchopped) and sunnhemp (chopped) fresh plants (45 days) were arranged in alternate layers (V/V: 1foot: 1 foot) for enriched composting.

The materials were allowed to decompose under rain for four months in rainy season. Similar time was required for enriched compost formation in a field level demonstration at Village Kalapunja, Paschim Midnapur, and WB. The material was turned over and mixed after 90 days. The whole material was composted to dark brown sticky matter like well rotten moist FYM. The material was converted to dough (Fig. 4) and the manure was molded to blocks in small plastic buckets (Fig. 5, 4-5 lit capacity). A thin moist plastic film was first laid inside the bucket and then the compost dough was filled in the bucket (full to the brim), it was pressurised with palms and turned upside down to get the block (Fig. 5). The blocks were sundried in shade. For chemical analysis, ground manure was used.

\section{Easy straw compost without sunnhemp}

Where sunnhemp is not available, in between two straw layers a mixture of $2 \mathrm{~kg}$ field soil, one $\mathrm{Kg}$ mustard cake, one kg N:P:K::10:26:26 and $2 \mathrm{~kg}$ FYM, has to be added as accelerator materials. The straw must be kept wet by irrigation for its faster decomposition (Fig. 6 \&7). Initially $5 \mathrm{~kg}$ FYM has to be spread at the floor of the pit for supply of decomposing organisms and earth worms etc. for timely decomposition. After 90 days spading is necessary for turning of lower material to upper side and vice-versa and proper aeration.

For this an experiment was done at ICARCRIJAF. The field level demonstration was made in collaboration with Asstt. Director of Agriculture, Chapra Block Nadia, Deptt. Agril. Govt. of WB in the year 2020. The manure formation process took 5-6 months.

For entry of sufficient oxygen up to bottom layer for well decomposition, perpendicular holes were made using bamboo poles ramming it on compost material with a weight material (Fig. 7).

\section{Results and Discussion}

The sunnhemp and straw compost is dark colour, odor less, easy to handle. The sunhemp and straw compost contained 1.95 per cent nitrogen and 0.848 per cent phosphorus (Table 1). The bulk density of the said material is $0.4-0.5 \mathrm{~g} / \mathrm{cc}$. The nitrogen content was much higher than conventional dry farm yard manure (Hand Book of Argil 1971). Available phosphorus and potassium were 0.001 and 0.208 per cent respectively (Gloria et al; 2016). This compost is richer 
than usual dry farm yard manure. Similar was the compost (1.7 to $2.1 \%$ nitrogen, 1.3 to 1.5 $\%$ phosphorus and 1.4-1.6 percent potassium) when rice straw compost was made using Aspergillus awamori and rock phosphate (Rupela et al., ICRISAT) which increased rice yield by 4-9\%. For composting in in situ condition in one acre, suitable pit $(6 \mathrm{~m} \mathrm{X} 2 \mathrm{~m}$ $\mathrm{x} 1.3 \mathrm{~m}$ ) has to be dug out in the lowest corner of the field for better decomposition of rice straw with sunnhemp (1:1 ratio $\mathrm{v} / \mathrm{v})$ using runoff water or water from irrigation.

Table.1 Nutrient composition of enriched wheat/rice straw compost

\begin{tabular}{|l|c|c|}
\hline $\begin{array}{c}\text { Chemical } \\
\text { composition }\end{array}$ & $\begin{array}{c}\text { Sunnhemp and wheat/rice straw } \\
\text { compost }\end{array}$ & Dry farm yard manure \\
\hline $\mathbf{N}(\mathbf{\%})$ & 1.95 & $0.4-0.5$ \\
\hline $\mathbf{P}_{\mathbf{2}} \mathbf{O}_{\mathbf{5}}(\mathbf{\%})$ & 0.848 & $0.3-0.9$ \\
\hline $\mathbf{K}(\mathbf{\%})$ & -- & $0.3-1.9$ \\
\hline Bulk density (g/cc) & $0.4-0.5$ & -- \\
\hline
\end{tabular}

Fig.1 Rice straw burning in field condition at farmers' field

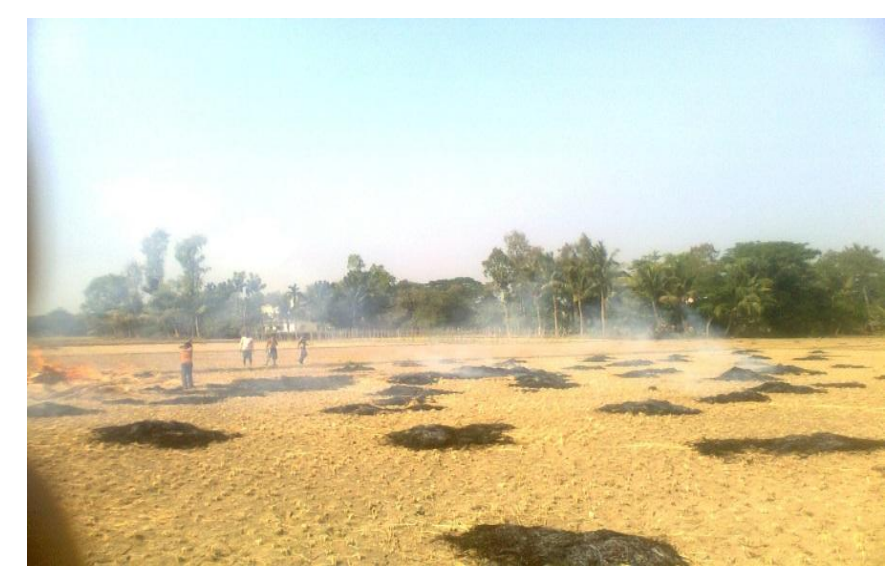

Fig.2 Tender sunnhemp harvest by brush cutter for composting

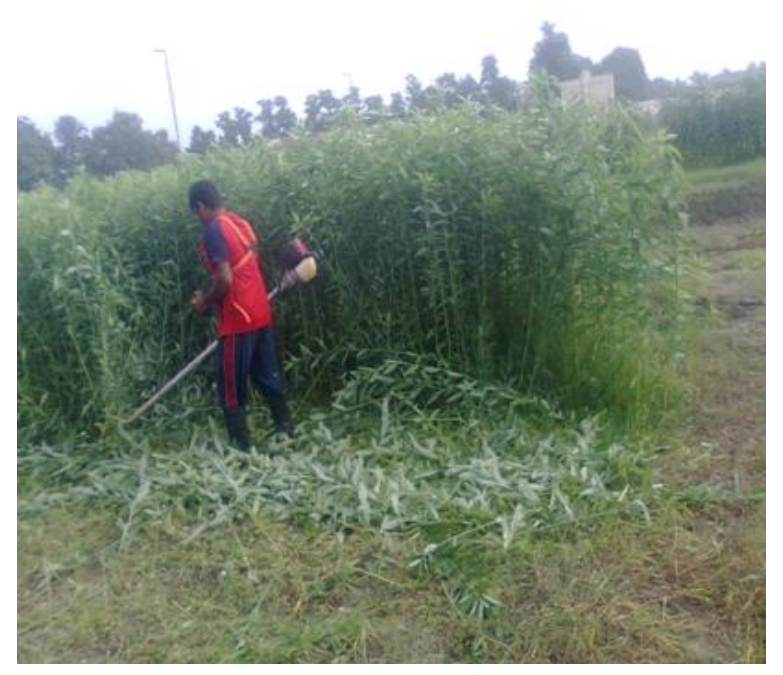


Fig.3 Arrangement of rice straw/wheat straw and sunnhemp in alternate layers for compost development

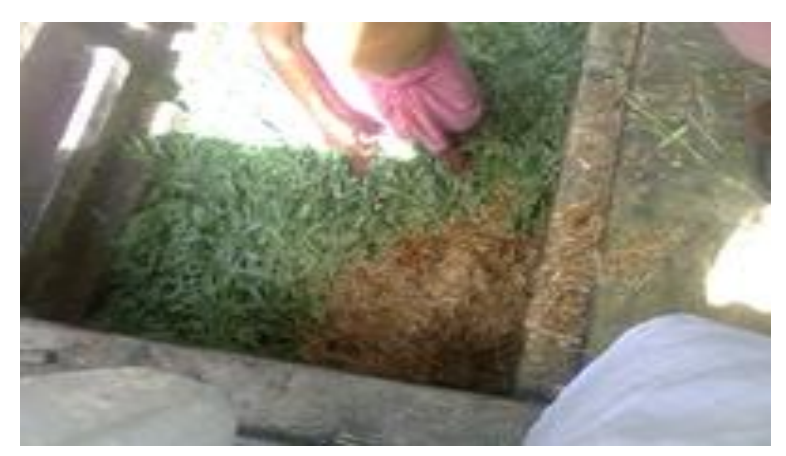

Fig.4 Matured compost being doughed for moulding into blocks

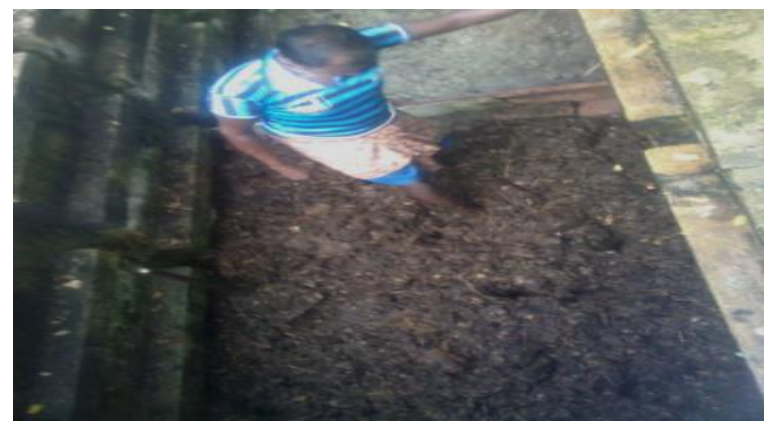

Fig.5 Manure blocks from straw and sunnhemp compost using plastic bucket

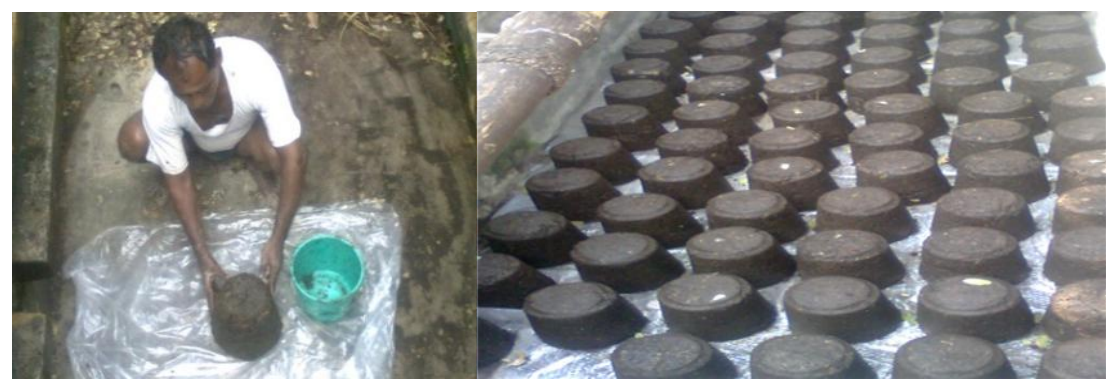

Fig.6 In situ compost preparation from rice straw at Chapra Block, Nadia, WB-2020

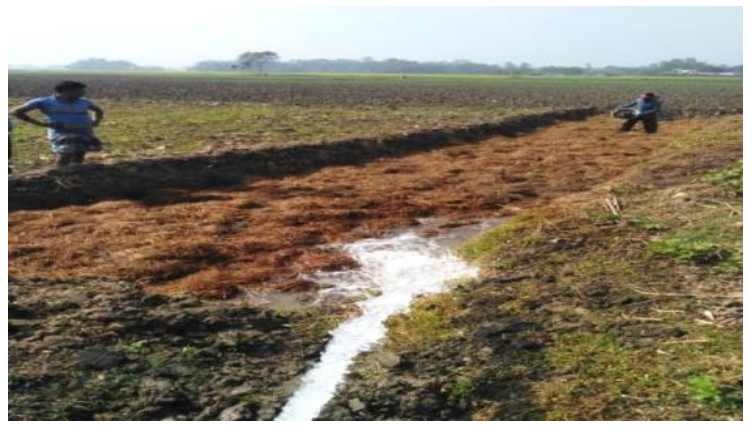


Fig.7 Matured insitu straw manure after 5 months and perpendicular hoes for air supply and quicker decomposition, ICAR-CRIJAF

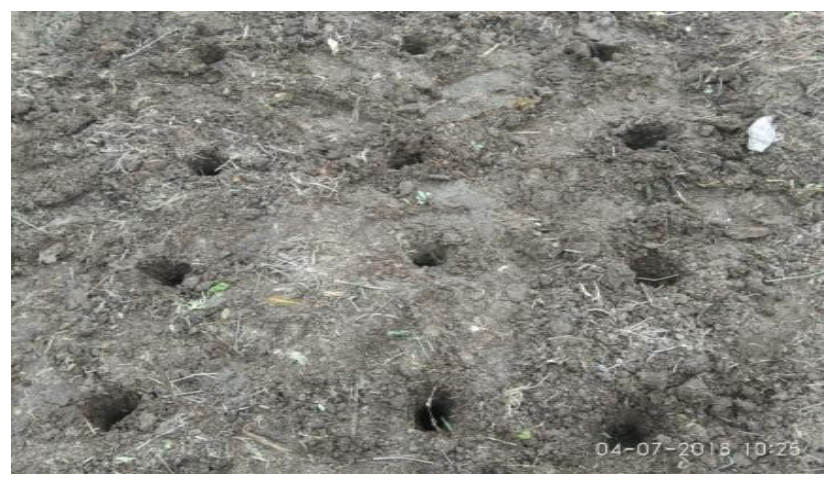

Sunnhemp may be grown after rice or wheat harvest from April to $15^{\text {th }}$ of May when the fields usually remain fallow till the onset of monsoon. The tender sunnhemp may be cut by brush cutter and dragged by cultivator to the compost pits where the cereal residues and this nitrogen rich tender material can be arranged in 1:1 layer for composting.

Application of this enriched compost showed no adverse effect on growth and yield of Kharif radish (cv. Pusa chetki) at ICARCRIJAF farm and in floriculture in home gardens. Sunhemp and wheat/rice straw compost can be utilized in different agrohorticultural purposes including fisheries. Chakraborty et al., 2010 reported highest yield $(4000 \mathrm{~kg} / \mathrm{ah}$ at 90 DAS) of fish in vats applied with vermicomposting is attributed to its highest manorial valued. Large scale production of compost from rice and wheat straw will reduce the dependence on chemical fertilizer, keep the soil healthy and maintain clean environment avoiding straw burning.

\section{Acknowledgement}

The author is thankful to the authority of ICAR and ICAR-CRIJAF for providing logistic supports for conducting the experiments and its dissemination in farmer's field. The author also acknowledges Dr. Pranab Hembram, ADA, Chapra Block,
Nadia, and Deptt. Of Agril. Govt. of WB for his help in preparing easy compost from rice residues at Chapra, Nadia.

\section{References}

Chakrabarty, D, Das, S.K., M.K. Das1 and M.P. Bag (2010).Assessment of Vermicompost as Direct Application Manure in Fish Farming Ponds. Turkish Journal of Fisheries and Aquatic Sciences 10: 47-52 (2010)

Chang CH, Liu CC, Tseng PY. 2013. Emissions inventory for rice straw open burning in Taiwan based on burned area classification and mapping using Formosat-2 satellite imagery. Aerosol Air Qual. Res. 13:474-87.

Engling G, Lee J, Tsai Y. 2009. Size-resolved anhydrosugar composition in smoke aerosol from controlled field burning of rice straw. Aerosol Sci. Tech. 43(7): 662-672. doi: $10.1080 / 02786820902825113$.

Ghorai, A.K. and Kundu D.K.(2016). Avoid burning rice and wheat straw. Compost it using sunnnhemp and minimize green house gas emission. Proceed. National Seminar on ' Resource Based Inclusive Agriculture and Rural Development: Challenges and opportunities" under climate resilient agriculture and stress 
management" held at Faculty of IRDM, Ramkrishna mision Vivekanadda University (RKMVU) from 15-16 Januray,2016, Narendrapur, Kolkata, WB, India. pp39.

Hand book of Agriculture (1971). Chemical composition of principal oil cakes. ICAR, New Delhi (pp 236)

In-field rice straw management (IIRI)http://www.knowledgebank.irri. org/step-by-stepproduction/postharvest/rice-byproducts/rice-straw/in-field-rice-strawmanagement

IRRI Rice Knowledge Bank. Composting of rice residues -. How to compost from rice residues. www.knowledgebank.irri.org

Jenkins BM, Mehlschau JJ, Williams RB, Solomon C, Balmes J, Kleinman M, Smith N. 2003. Rice straw smoke generation system for controlled human inhalation exposures. Aerosol Sci. Technol. 37(5):437-454. doi:10.1080/02786820300977.

Mandal KG, Misra AK, Hati KM, Bandyopadhyay KK, Ghosh PK, Mohanty M. 2004. Rice residue management options and effects on soil properties and crop productivity. Food Agric. Environ. 2:224-231.

Manna, M.and. Asha Sahu (2103). Rapid
Composting Methods. Division of Soil Biology, Indian Institute of Soil Science, IISS, Bhopal, (M.P.)

Oanh NT, Ly BT, Tipayarom D. 2011. Characterization of particulate matter emission from open burning of rice straw. Atmos. Environ. 45(2): 493502.

doi:10.1016/j.atmosenv.2010.09.023.

Ponnamperuma FN. 1984. Straw as a source of nutrients for wetland rice. Organic Matter and Rice. International Rice Research Institute, Los Baños, Philippines. p 117-135.

Rashid, M. A. Horiuchi, T and OBA, S (2001) Enrichment of Rice Straw Compost by Adding Cow Dung and Soybean Plants and its Effect son Wheat Yield and Soil Nutrients. Jpn.

J. Crop Sci. 70 (2): 55-56

Rupela, O P and Sidhu, B S and Gopalakrishnan, S and Saini, S K and Beri, V (1998) Preparation and evaluation of Rice-Straw Compost. In: 2nd Research Co-ordination meeting of the FAO/IAEA Co-ordinated Research Project on "The use of nuclear techniques in the management of organic matters to enhance soil productivity and crop yields", 20-24 April 1998 , Vienna, Austria.

\section{How to cite this article:}

Ghorai, A. K. 2020. In situ Enriched Compost Preparation from Rice and Wheat Straw using Tender Sunnhemp to Minimise Field Burning. Int.J.Curr.Microbiol.App.Sci. 9(09): 627-633. doi: https://doi.org/10.20546/ijcmas.2020.909.079 